Копитіна Я.М. ${ }^{1}$, Арєшина Ю.Б. ${ }^{1}$, Перепеченко Л.М. ${ }^{2}$, Бугаєнко Т.В. ${ }^{1}$, Беспалова О.О. ${ }^{1}$

\title{
Розвиток просторового оріснтування засобами фізичної терапії осіб із тяжкими порушенями зору та сліпотою у санаторно-курортних умовах
}

\author{
${ }^{1}$ Сумський державний педагогічний університет імені А.С. Макаренка, Навчально-науковий інститут \\ фізичної культури, кафедра здоров'я, фізичної терапії, реабілітації та ерготерапії, м. Суми, Україна \\ ${ }^{2}$ Київський міський Центр соціальної, професійної та трудової реабілітації інвалідів, м. Київ, Україна
}

yana@kopytin.in.ua, julia.opheart@gmail.com, panilesya@ukr.net, bugaenkotv@ukr.net, i-ozon777@bigmir.net

Копытина Я.Н. ${ }^{1}$, Арешина Ю.Б. ${ }^{1}$,

Перепеченко О.Н. ${ }^{2}$, Бугаенко Т.В. ${ }^{1}$, Беспалова О.А. ${ }^{1}$

Развитие пространственной ориентации средствами физической терапии у лиц с тяжелыми нарушениями зрения и слепотой в санаторно-курортных условиях ${ }^{1}$ Сумской государственный педагогический университет

имени А.С. Макаренко, Учебно-научный институт физической культуры, кафедра здоровья, физической терапии, реабилитации и эрготерапии, г. Сумы, Украина

${ }^{2}$ Киевский городской центр социальной, профессиональной и трудовой реабилитации инвалидов, г. Киев, Украина
Kopytina Ya.M. ${ }^{1}$, Arieshyna Yu.B. ${ }^{1}$,

Perepechenko L.M. ${ }^{2}$, Buhaienko T.V. ${ }^{1}$, Bespalova O.O. ${ }^{1}$ Spatial orientation development in persons with severe visual impairments and blindness

by means of physical therapy in a sanatorium stage ${ }^{1}$ Sumy State pedagogical university named after A.S. Makarenko, Educational-scientific institute of physical culture, Department of health, physical therapy, rehabilitation and ergotherapy, Sumy, Ukraine,

${ }^{2} \mathrm{Kyiv}$ city center for social, professional and labor rehabilitation of the disabled, Kyiv, Ukraine

\section{Зв'язок роботи з науковими темами, планами}

Дослідження виконано згідно 3 колективною науково-дослідною темою кафедри здоров'я, фізичної терапії, реабілітації та ерготерапії Сумського державного педагогічного університету імені А.С. Макаренка «Теоретико-методологічні і організаційно-методичні проблеми здоров'я, фізичної реабілітації і корекційної педагогіки» (№ держреєстрації 0115U005933).

\section{Вступ}

Орієнтування у просторі - одна 3 актуальних складних проблем, що входять до галузі фізичної терапії та соціальної адаптації слабозорих та незрячих осіб. Це обумовлено тим, що успішність інтеграції людини із тяжкими порушеннями зору багато у чому залежить від іiі здатності самостійно орієнтуватися у просторі свого будинку, на робочому місці, на вулицях міста, у різних установах, організаціях, у громадських місцях та відчувати себе максимально комфортно і впевнено, наскільки це можливо [1-3].

Під просторовим орієнтуванням розуміють вміння визначати місце свого розташування на місцевості та напрям свого руху щодо сторін горизонту або об'єктів при повній або частковій відсутності зору за допомогою збережених органів чуття. Орієнтуватися у навколишньому просторі означає вміти визначати величину і форму того простору, у якому знаходиться особа із патологією зорового аналізатора, визначати величину і форму тих предметів, які знаходяться у даному просторі, їх взаємне розташування, а також своє положення відносно кожного з них. Людині для успішної діяльності, адаптації у суспільстві необхідне вміння орієнтуватися у просторі. Отже, одним 3 найважливіших завдань фізичної терапії осіб із особливими потребами, які мають патологію зорового аналізатора, $\epsilon$ навчання іх просторовому орієнтуванню [4-7].

Вищезазначена категорія осіб характеризується своєрідністю психофізичної сфери, що проявляється у недостатній моторній активності, складнощах формування рухової сфери. У свою чергу, це викликає у осіб із особливими потребами, які мають патологію зорового аналізатора, труднощі просторового орієнтування, а недоліки у його розвитку, у свою чергу, і надалі обмежують їх самостійність і активність у всіх сферах діяльності. При цьому особам даної категорії (особливо 3 тяжкими порушеннями зору) самостійно практично неможливо опанувати навички просторового орієнтування. Тому вони відчувають потребу в систематичному цілеспрямованому навчанні $[2,8-10]$.

У дефектологічних дослідженнях відзначається, що в умовах тотальної і парціальної сліпоти порушуються взаємозв'язки між суб'єктом і об'єктом, що обумовлює появу дезадаптуючих процесів, які призводять до гальмування розвитку особистості та соціального досвіду людини як суб'єкта діяльності. У більшості дорослих (пізноосліплих), які мають тотальну і парціальну сліпоту, 
відзначено низькі перцептивно-орієнтаційні рівні взаємодії з відкритим простором $[4,5]$.

Так, у осіб із тяжкими порушенням зору (у тотально сліпих та сліпих із незначним залишковим зором) спостерігається страх перед пересуванням у просторі, що пояснюється недостатньою сформованістю такого основного руху, як ходьба. Це не означає повної неможливості самостійно пересуватися пішки, але вони потребують постійної допомоги оточуючих (помічника, поводиря). Коли ж дані особи роблять спроби ходити самостійно, вони можуть натикатися на меблі та інші предмети, що трапляються їм на шляху, спотикаються об килим або поріг, падають, вдаряються та можуть сильно травмуватися. Це відбувається через те, що техніку ходьби, яка включає і певне положення тіла, і постановку стоп, і відчуття рівноваги, і координацію рухів рук та ніг, не відпрацьовано і не доведено до автоматизму $[1,3,8]$.

Під час самостійного пересування у приміщенні або за його межами особи із патологією органів зору зазвичай напружені, невпевнені, рухи їх скуті, вони бояться відірвати ступні від підлоги, «човгаючи» під час пересування. Через це під час ходьби всі зусилля й увага прикладаються до того, щоб не наштовхнутися на щонебудь, не впасти, не вдаритися, оскільки спрацьовують інстинкти самозбереження. Як наслідок, з'являється страх самостійного пересування у просторі, неприродне небажання дізнатися, що знаходиться навколо $[2,8,10]$.

Доцільно проводити реабілітаційне навчання для осіб із тяжкими порушеннями зору та сліпотою, що включатиме навчання правильно ходити, осмислювати свої сприйняття (слухові, дотикові, нюхові та ін.), навчання впізнавати та розпізнавати оточуючі предмети, ознайомлення із призначенням і розташуванням у тому приміщенні, де вони знаходяться. Це необхідно, оскільки, навчившись керувати своїм тілом i розуміти, що розташоване навколо, людина з особливими потребами переключає свою увагу на дослідження навколишнього світу $[1,9]$.

Згідно даних літературних джерел, одним із критеріїв розвитку навичок просторового орієнтування $\epsilon$ можливість відтворення заданих параметрів руху (вектору, амплітуди і т. д.) [5]. Однак не було виявлено достатньо спеціальних досліджень, що стосуються дорослого контингенту із тяжкими порушеннями зору та сліпотою, щодо особливостей впливу засобів фізичної терапії на дані показники.

Мета роботи - 3'ясувати можливості впливу засобів фізичної терапії на розвиток навичок просторового орієнтування у осіб з особливими потребами, які мають тяжкі порушення зору та сліпоту.

\section{Матеріали та методи}

У дослідженні взяли участь 245 осіб із інвалідністю віком від 18 до 35 років, які мали тяжкі порушення зору або сліпоту. Вони проходили курс фізичної терапії на базі Західного реабілітаційно-спортивного центру Національного комітету спорту інвалідів України (с.Яворів, Турківський р-он, Львівська обл.) у 2016-2019 рр.
Кількість пацієнтів із залишком зору складала 155 осіб $(63,3 \%)$, незрячих - 90 осіб (36,7\%). Інвалідність першої групи мали 183 особи (74,7\%), другої - 62 особи $(25,3 \%)$. Програму фізичної терапії пройшли 136 жінок (55,5\%) та 109 чоловіків (44,5\%). Середній вік пацієнтів становив $28,29 \pm 5,19$ років. Щороку проводилось по 1 літньому та 1 зимовому заїзду. Тривалість кожного заїзду - два тижня.

При оцінці точності просторового параметру рухів було застосовано пробу на пропріорецептивну чутливість (оцінку кінестезіі). Обстежуваного просили зайняти вихідне положення сидячи на стільці та відтворити заздалегідь заданий кут згинання у ліктьовому суглобі безпосереднім виконанням даного руху [11]. Спочатку виконували по три тренувальні спроби згинань на заданий кут за допомогою рук фізичного терапевта та під контролем зору досліджуваних у випадку його часткового збереження, а після цього повторювали згинання iз заплющеними очима. Проводилися по три серії згинань руки: згинання на малий (гострий) кут $\left(45^{\circ}\right)$, згинання на середній (прямий) кут $\left(90^{\circ}\right)$, згинання на великий (тупий) кут $\left(135^{\circ}\right)$. Такі кути згинання фіксувалися на декілька секунд. Під час фіксації проводилося вимірювання кута згинання у ліктьовому суглобі за допомогою гоніометра. Після цього підраховувалася різниця між фактичним результатом та заданою величиною. За даними Б.В. Сермеєва, В.С. Ніколаєва (1980), при високому рівні розвитку точності у незрячих величина помилки має становити не більше ніж 2-3, що ми й вважали показниками норми даної проби [12].

Точність вимірювання складала $1^{\circ}$. Дану пробу проводили двічі - на початку та наприкінці курсу фізичної терапії.

\section{Результати дослідження та їх обговорення}

Здійснення реабілітаційних заходів для осіб із особливими потребами, які мають патологію органів зору, передбачало наступні стадії реабілітаційної технології: здійснення оцінювання вихідного стану досліджуваних показників, визначення реабілітаційного потенціалу, складання індивідуальної програми фізичної терапії та впровадження іiі у практику, здійснення повторного оцінювання фізичного на функціонального стану. Після реалізації цих стадій настає можливість оцінити ефективність від реабілітаційного втручання.

Пацієнти проходили курс фізичної терапії у санаторно-курортних умовах, який базувався на комплексному використанні різних засобів рухової активності у поєднанні 3 навчанням просторовому орієнтуванню.

Метою навчання слабозорих та незрячих просторовому орієнтуванню було формування навичок, що дозволяють вільно орієнтуватися і самостійно пересуватися за будь-яких обставин. Дослідники відзначають, що рівень просторового орієнтування залежить від ступеню цілісного сприйняття предметного світу $[4,5,10]$.

У процесі навчання просторовому орієнтуванню було проведено ознайомлення 3 найближчим оточенням, 
пацієнтів попереджали про потенційну небезпеку, навчали уникати iї, спираючись на можливості своїх збережених аналізаторів. У навчанні також було використано поєднання дистантного слухового сприйняття 3 контактним тактильним, встановлення зв'язку між об'єктами, які сприймаються за допомогою дотику, та їх звуковими характеристиками. Це дозволяло виділяти звуки як сигнальні ознаки предметів, об'єктів і явищ навколишнього світу i використовувати їх при орієнтуванні.

Реабілітаційне навчання відповідно до гостроти зору включало: диференціацію світлових та колірних плям, співвідношення їх із конкретними предметами або явищами, фіксування погляду на предметах, виділення силуетів або контурів предметів, розрізнення на близькій відстані раніше вивчених предметів.

Заняття 3 навчання просторовому орієнтуванню частково вирішували такі завдання:

- вдосконалення техніки ходьби;

- формування сприйняття предметів та їх розташування у просторі, що максимально відповідає дійсності;

- навчання користуватися залишковим зором при орієнтуванні у просторі;

- навчання користуватися збереженими аналізаторами при орієнтуванні у просторі;

- подолання страху перед самостійним пересуванням у просторі.

Організація занять із навчання просторовому орієнтуванню відбувалася таким чином, щоб вирішити основні проблеми, 3 якими стикаються особи із особливими потребами, які мають патологію органів зору.

По-перше, для осіб, які мають залишок зору або сліпоту, властиве невміння отримувати інформацію про простір за допомогою збережених інших аналізаторів та використовувати їх у самостійному практичному орієнтуванні. Тому одним 3 найважливіших завдань було формування полісенсорного сприйняття оточуючого середовища. Відсутність даного вміння у незрячих не дозволяє їм бути досить активними і самостійними при орієнтуванні навіть у найближчому просторі.

Завдання на свідоме включення дотику і слуху для сприйняття предметів і об’єктів, а також залишкового зору і слуху - до дотикового сприйняття сприяло збільшенню точності їх впізнавання.

Це важливо, оскільки навколишні предмети та об'єкти, які особи із патологію органів зору навчилися впізнавати або за допомогою одного певного аналізатора, або ж полісенсорно, ставали для них надійними орієнтирами, що допомагали вільно, самостійно пересуватися у будь-якому, навіть незнайомому, просторі. Володіння зазначеним контингентом навичками полісенсорного сприйняття простору і застосування даних навичок у самостійному орієнтуванні значно розширює можливості пізнання навколишнього світу.

По-друге, особи із особливими потребами, які мають патологію органів зору, характеризуються недостатнім запасом предметних і просторових уявлень, невмінням позначати вербально просторові ознаки та напрямки, які сприймаються. Це також обумовлює їх труднощі при орієнтуванні. У зв'язку з цим усі дії осіб із тяжкими порушеннями зору та сліпотою щодо виділення просторових ознак і визначення просторових напрямків супроводжувалися їх словесними позначеннями. У даному випадку, на основі полісенсорного сприйняття, закріпленого у слові, створювався узагальнений образ простору.

По-третє, у значної частини осіб із патологією органів зору (особливо при глибокій зоровій патології) спостерігаються також порушення мікро- та макрокоординації рухів, що робить їх орієнтування у просторі сповільненим і неточним. Для корекції даних порушень застосовувалося постійне (тривале) тренування у виконанні відповідних рухів зі значною кількістю повторів (не менше 10-12 разів)

Конкретні завдання які виконувалися під час навчання просторовому орієнтуванню, були розподілені на окремі тематичні блоки.

Блок «Фізична культура» включав:

- розвиток зорово-рухової орієнтації;

- закріплення вміння орієнтуватися у просторі за допомогою збережених аналізаторів через основні рухи, загальнорозвивальні вправи, рухливі ігри.

У фізичних вправах розвивалися не тільки рухові, а й зорові, слухові функції осіб із патологією органів зору, формувалися прийоми макро- та мікропросторового орієнтування.

Блок «Комунікація» включав завдання, спрямовані на:

- вербальне позначення просторового розташування частин свого тіла;

- чітке диференціювання основних напрямків простору, словесне позначення їх відповідними термінами (праворуч - направо, зліва - наліво і т.д.; стіл стоїть біля вікна, картина висить на стіні, книга стоїть у шафі на верхній полиці і т.д.);

- обговорення дій при розташуванні предметів у реальному просторі та на схемі.

Первинне проведення проби на пропріорецептивну чутливість показало, що відхилення від заданого малого кута згинання правої руки у ліктьовому суглобі складало $11,33 \pm 15,32^{\circ}$, у лівій руці $-8,61 \pm 10,14^{\circ}(\mathrm{p}=0,39)$. При проведенні проби на середній кут згинання було отримано наступні показники похибки проведення дослідження: права рука $-6,43 \pm 11,24^{\circ}$, ліва рука $-8,55 \pm 11,59^{\circ}(\mathrm{p}=0,45)$. Згинання на великий кут супроводжувалося відхиленням від норми на правій руці на $9,69 \pm 12,12^{\circ}$, на лівій руці $10,85 \pm 12,03^{\circ}(\mathrm{p}=0,69)$ (табл. 1$)$.

Задовільні тести згинання правої руки на гострий кут було зафіксовано у 78 осіб (32\%), на прямий кут у 101 особи (41\%), на тупий кут - у 59 осіб $(24,1 \%)$.

Задовільні тести згинання лівої руки на гострий кут було зафіксовано у 93 осіб (38\%), на прямий кут - у 108 осіб (44\%), на тупий кут - у 37 осіб (15\%).

Отримані результати свідчили про недостатню точність просторового параметру рухів у обстежених та фактично підтвердили наявність проблеми із просторовою орієнтацією. 
Таблиця 1. Вихідні результати тестування пропріоцептивної чутливості осіб із тяжкими порушеннями зору та сліпотою

\begin{tabular}{|c|c|c|}
\hline \multirow{2}{*}{ Серії згинання } & \multicolumn{2}{|c|}{ Результати тестування $(\mathrm{n}=\mathbf{2 4 5})$} \\
\hline & Права рука $(\mathrm{M} \pm \mathrm{m})$ & Ліва рука $(M \pm m)$ \\
\hline \multirow[t]{2}{*}{ Малий кут, о } & $11,33 \pm 15,32$ & $8,61 \pm 10,14$ \\
\hline & \multicolumn{2}{|c|}{$\mathrm{p}=0,39$} \\
\hline \multirow[t]{2}{*}{ Середній кут, ${ }^{\circ}$} & $6,43 \pm 11,24$ & $8,55 \pm 11,59$ \\
\hline & \multicolumn{2}{|c|}{$\mathrm{p}=0,45$} \\
\hline \multirow[t]{2}{*}{ Великий кут, ${ }^{\circ}$} & $9,69 \pm 12,12$ & $10,85 \pm 12,03$ \\
\hline & \multicolumn{2}{|c|}{$\mathrm{p}=0,69$} \\
\hline
\end{tabular}

Після запровадження розробленої програми фізичної терапії було здійснено повторне тестування пропріоцептивної чутливості осіб із тяжкими порушеннями зору та сліпотою, що надало можливість спостерігати певну динаміку даного параметру.

Похибка амплітуди у серії згинань у правому ліктьовому суглобі на малий кут становила $10,38 \pm 14,78^{\circ}$ $(\mathrm{p}=0,79$ у порівнянні з початковими показниками), на лівій руці $-10,72 \pm 12,11^{\circ}$ ( $\mathrm{p}=0,49$ у порівнянні 3 початковими показниками).
Позитивна динаміка була зафіксована також при згинаннях у ліктьовому суглобі на середній кут. На правій руці показники похибки сягнули $7,81 \pm 12,36^{\circ}$ ( $\mathrm{p}=0,26$ у порівнянні з початковими показниками), на лівій руці $9,16 \pm 12,13^{\circ} \quad(\mathrm{p}=0,83$ у порівнянні 3 початковими показниками).

При згинаннях на великий кут правої руки похибка становила $7,19 \pm 6,13^{\circ}$ ( $\mathrm{p}=0,29$ у порівнянні $з$ початковими

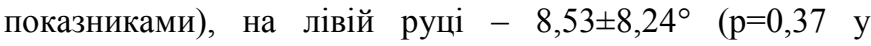
порівнянні з початковими показниками) (табл. 2).

Таблиця 2. Результати повторного тестування пропріоцептивної чутливості осіб із тяжкими порушеннями зору та сліпотою

\begin{tabular}{|c|c|c|}
\hline \multirow{2}{*}{ Серії згинання } & \multicolumn{2}{|c|}{ Результати тестування $(\mathrm{n}=\mathbf{2 4 5})$} \\
\hline & Права рука $(\mathbf{M} \pm \mathbf{m})$ & Ліва рука $(\mathrm{M} \pm \mathbf{m})$ \\
\hline \multirow[t]{2}{*}{ Малий кут, ${ }^{\circ}$} & $10,38 \pm 14,78$ & $10,72 \pm 14,11$ \\
\hline & \multicolumn{2}{|c|}{$\mathrm{p}=0,93$} \\
\hline \multirow[t]{2}{*}{ Середній кут, ${ }^{\circ}$} & $7,81 \pm 12,36$ & $9,16 \pm 12,13$ \\
\hline & \multicolumn{2}{|c|}{$\mathrm{p}=0,66$} \\
\hline \multirow[t]{2}{*}{ Великий кут, } & $7,19 \pm 6,13$ & $8,53 \pm 8,24$ \\
\hline & \multicolumn{2}{|c|}{$\mathrm{p}=0,46$} \\
\hline
\end{tabular}

Порівняльний аналіз середніх показників похибки амплітуди згинань дав змогу констатувати поліпшення пропріорецептивної чутливості осіб із тяжкими порушеннями зору та сліпотою. Так, похибка амплітуди у серії згинань на малий кут правої кінцівки зменшилась на 8,3\%, лівої кінцівки - збільшилась на 19,5\%. У серіях згинань на середній кут похибка амплітуди згинання правої руки збільшилась на 17,7\%, на лівій кінцівці збільшилась на 6,7\%. При згинаннях на великий кут на правій руці похибка амплітуди згинання зменшилась на $25,8 \%$, на лівій руці - на 21,4\%.

Тест на повторне згинання правої руки у ліктьовому суглобі на гострий кут після проходження програми фізичної терапії виконали 101 особа (41\%), на прямий кут -150 осіб (61\%), на тупий кут -81 особа $(33 \%)$.

Тест на повторне згинання лівої руки у ліктьовому суглобі на гострий кут після проходження програми фізичної терапії виконали 115 осіб (47\%), на прямий кут 123 особи (51\%), на тупий кут - 108 осіб (44\%) (рис.).

Перспективи подальших досліджень полягають у розробці індивідуальних програм фізичної терапії із застосуванням ерготерапії, що дозволить удосконалювати набуті навички просторового орієнтування та самообслуговування осіб із тяжкими порушеннями зору та сліпотою у звичних побутових умовах. 


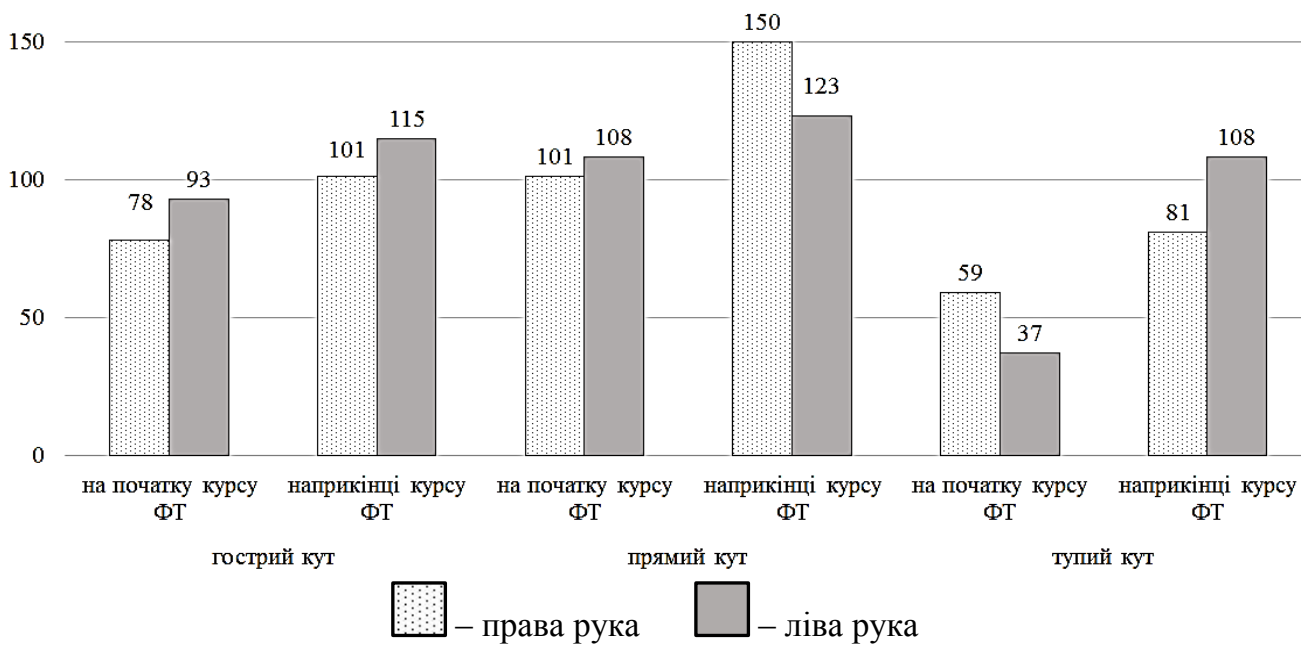

Рис. Динаміка кількості осіб, які вдало виконали пробу на пропріорецептивну чутливість, абс.

\section{Висновки}

Первинне проведення проби на пропріорецептивну чутливість засвідчило наявність проблеми 3 відчуттям власного тіла та його окремих сегментів у просторі, складністю відтворення заданих параметрів руху без контролю тіла зоровим аналізатором, а лише за рахунок сприйняття інформації за допомогою збереженого слухового аналізатору під керівництвом фізичного терапевта у осіб із тяжкими порушеннями зору та сліпотою.

Частина розробленої програми фізичної терапії, що була спрямована на розвиток та вдосконалення пропріорецептивної чутливості, мала на меті навчити пацієнтів даної групи максимально ефективно володіти збереженими аналізаторами під час переміщення для розвитку просторової орієнтації. У результаті її систематичного і цілеспрямованого застосування вдалося досягти позитивної динаміки такого показника, як точність просторового параметру руху. Це створило підгрунтя для подальшого формування пропріорецептивної чутливості та поліпшення просторової орієнтації у даного контингенту осіб.

\section{Література}

1. Наумов МН. Обучение слепых пространственной ориентировке. Москва: ВОС; 1982. 46 с.

2. Толмачев РА. Адаптивная физическая культура и реабилитация слепых и слабовидящих. Москва: Советский спорт; 2004. 108 с.

3. Fernandes H, Costa P, Filipe V, Paredes H, Barroso J. A review of assistive spatial orientation and navigation technologies for the visually impaired. Univ Access Inf Soc. 2019;18(1):155-68.

4. Журов ВВ. Розвиток просторової перцепції у осліплих осіб зрілого віку [автореферат]. Київ: Ін-т дефектології АПН України; 2002. 18 с.

5. Duquette J. Spatial orientation in adolescents with visual impairment : Related factors and avenues for assessment: information monitoring summary. Longueuil: INLB; 2012. 17 p.

6. Lahav O, Schloerb DW, Srinivasan MA. Virtual Environments for People Who Are Visually Impaired Integrated into an Orientation and Mobility Program. J Vis Impair Blind. 2015;109(1):5-16.

7. Бенесько ОО. Комплексна реабілітація інвалідів по зору в умовах реабілітаційного центру. В: Савчук НА, редактор. V Міжнародна науково-практична конференція Сучасний світ і незрячі: людина з інвалідністю у правовій державі; 2011 Жовт 20-21; Луцьк. Київ; 2011. с. 163-7.

8. Eichel KJ. Mannerisms of the blind: a review of literature. J Vis Impair Blind. 1978;72(4):125-30.

9. Азарян АР. Правильная ходьба и манера движений как важное условие социализации слепых и слабовидящих. Физическое воспитание детей с нарушением зрения в детском саду и начальной школе. 2005;(5):14-7.

10. Schinazi VR, Thrash T, Chebat D-R. Spatial navigation by congenitally blind individuals. Wiley Interdiscip Rev Cogn Sci. 2016;7(1):37-58.

11. Беляев ИГ. Развитие функций двигательного анализатора у детей дошкольного возраста [автореферат]. Пермь: Пермский гос. пед. ин-т, 1961. 15 с.

12. Сермеев БВ, Николаев ВС. Физическая подготовка слепых с использованием тренажеров. М.: ВОС, 1980.48 с. 


\section{References}

1. Naumov MN. Obuchenie slepyih prostranstvennoy orientirovke. Moskva: VOS; $1982.46 \mathrm{~s}$.

2. Tolmachev RA. Adaptivnaya fizicheskaya kultura i reabilitatsiya slepyih i slabovidyaschih. Moskva: Sovetskiy sport; 2004. $108 \mathrm{~s}$.

3. Fernandes H, Costa P, Filipe V, Paredes H, Barroso J. A review of assistive spatial orientation and navigation technologies for the visually impaired. Univ Access Inf Soc. 2019;18(1):155-68.

4. Zhurov VV. Rozvytok prostorovoi pertseptsii u osliplykh osib zriloho viku [avtoreferat]. Kyiv: In-t defektolohii APN Ukrainy; 2002. 18 s.

5. Duquette J. Spatial orientation in adolescents with visual impairment : Related factors and avenues for assessment: information monitoring summary. Longueuil: INLB; 2012. 17 p.

6. Lahav O, Schloerb DW, Srinivasan MA. Virtual Environments for People Who Are Visually Impaired Integrated into an Orientation and Mobility Program. J Vis Impair Blind. 2015;109(1):5-16.

7. Benesko OO. Kompleksna reabilitatsiia invalidiv po zoru v umovakh reabilitatsiinoho tsentru. V: Savchuk NA, redaktor. V Mizhnarodna naukovo-praktychna konferentsiia Suchasnyi svit i nezriachi: liudyna z invalidnistiu u pravovii derzhavi; 2011 Zhovt 20-21; Lutsk. Kyiv; 2011. s. 163-7.

8. Eichel KJ. Mannerisms of the blind: a review of literature. J Vis Impair Blind. 1978;72(4):125-30.

9. Azaryan AR. Pravilnaya hodba i manera dvizheniy kak vazhnoe uslovie sotsializatsii slepyih i slabovidyaschih. Fizicheskoe vospitanie detey s narusheniem zreniya v detskom sadu i nachalnoy shkole. 2005;(5):14-7.

10. Schinazi VR, Thrash T, Chebat D-R. Spatial navigation by congenitally blind individuals. Wiley Interdiscip Rev Cogn Sci. 2016;7(1):37-58.

11. Belyaev IG. Razvitie funktsiy dvigatelnogo analizatora u detey doshkolnogo vozrasta [avtoreferat]. Perm: Permskiy gos. ped. in-t, 1961. $15 \mathrm{~s}$.

12. Sermeev BV, Nikolaev VS. Fizicheskaya podgotovka slepykh s ispolzovaniem trenazherov. M.: VOS, $1980.48 \mathrm{~s}$.

Дата надходження рукопису до редакції: 17.12 .2019 р.

Мета - розвиток та засвоєння навичок просторового орієнтування у осіб із тяжкими порушеннями зору та сліпотою засобами фізичної терапії у санаторно-курортних умовах.

Матеріали та методи. У дослідженні взяли участь 245 осіб із інвалідністю, які мають тяжкі порушення зору або сліпоту, віком від 18 до 35 років. При оцінці точності просторового параметру рухів було застосовано пробу на пропріорецептивну чутливість.

Результати. Первинне проведення проби на пропріорецептивну чутливість показало, що задовільні тести згинання правої руки на гострий кут було зафіксовано у 78 осіб (32\%), на прямий кут - 101 особа (41\%), на тупий кут 59 осіб (24,1\%), а задовільні тести згинання лівої руки на гострий кут було зафіксовано у 93 осіб (38\%), на прямий кут - 108 осіб (44\%), на тупий кут - 37 осіб (15\%). Повторний тест на згинання правої руки на гострий кут після проходження програми фізичної терапії виконали 101 особа (41\%), на прямий кут - 150 осіб (61\%), на тупий кут 81 особа (33\%). Тест на повторне згинання лівої руки на гострий кут після проходження програми фізичної терапії виконали 115 осіб (47\%), а прямий кут - 123 особи (51\%), на тупий кут - 108 осіб (44\%).

Висновки. Отримані дані свідчать про поліпшення пропріоцептивної чутливості обстежених осіб, які мають особливі потреби, із патологіями органів зору. терапія.

Ключові слова: пропріоцептивна чутливість, просторове орієнтування, сліпота, тяжкі порушення зору, фізична

Цель - развитие и усвоение навыков пространственной ориентировки у лиц с тяжелыми нарушениями зрения и слепотой средствами физической терапии в санаторно-курортных условиях.

Материалы и методы. В исследовании приняли участие 245 лиц с ограниченными возможностями, которые имеют тяжелые нарушения зрения или слепоту, в возрасте от 18 до 35 лет. При оценке точности пространственного параметра движений применялась проба на проприорецептивную чувствительность.

Результаты. Первичное проведение пробы на проприорецептивную чувствительность показало, что удовлетворительные тесты сгибания правой руки на острый угол было зафиксовано у 78 лиц (32\%), на прямой угол - у 101 человека (41\%), на тупой угол - у 59 лиц (24,1\%), а удовлетворительные тесты сгибания левой руки на острый угол были зафиксованы у 93 лиц (38\%), на прямой угол - у 108 человек (44\%), на тупой угол - у 37 лиц (15\%). Повторный тест на сгибание правой руки на острый угол после прохождения программы физической терапии выполнили 101 человек (41\%), на прямой угол - 150 человек (61\%), на тупой угол - 81 человек (33\%). Повторный тест на сгибание левой руки на острый угол после прохождения программы физической терапии выполнили 115 человек (47\%), на прямой угол - 123 человека $(51 \%)$, на тупой угол - 108 человек $(44 \%)$.

Выводы. Полученные данные свидетельствуют об улучшении проприоцептивной чувствительности обследованных лиц с особыми потребностями с патологией органов зрения. 
Ключевые слова: проприорецептивная чувствительность, пространственная ориентация, слепота, тяжелые нарушения органов зрения, физическая терапия.

Purpose - to develop and learn the spatial orientation skills in people with severe visual impairments and blindness by means of physical therapy at the sanatorium.

Materials and methods. The study was hold at the Western Rehabilitation and Sports Center of the National Committee of Disabled Sports of Ukraine (Yavoriv village, Turkiv district, Lviv region). The study involved 245 people of 18-35 years old with severe visual impairments or blindness. The test for proprioreceptive sensitivity was applied to evaluate the accuracy of the spatial parameter of movements.

Results. Patients took a physical therapy course at the sanatorium. The author's physical therapy program was based on the integration of various types of physical activity in combination with spatial orientation training. This physical therapy course included special classes in spatial orientation for the persons with severe visual impairment and blindness. The purpose of spatial orientation training for visually impaired and blind people was to develop skills that allowed them to navigate freely and move independently under any circumstances. The initial test for proprioreceptive sensitivity showed difficulties in fixing the limb in the desired angle of the elbow joint flexion in accordance with the test program. It indicated the complexity in the spatial orientation of persons with special needs who had pathology of vision. In the beginning of the study, the satisfactory results in flexion of the right elbow to the acute (small) angle were marked in 78 persons (32\%), to the right (average) angle - in 101 persons $(41 \%)$, and to the obtuse (large) angle - in 59 people $(24.1 \%)$. The satisfactory results in flexion of the left elbow to the same angles was marked in $93(38 \%), 108(44 \%)$ and 37 persons (15\%), respectively.

The initial deviation from the needed small angle of flexion of the right elbow joint was $11.33 \pm 15.32^{\circ}$, the left elbow $8.61 \pm 10.14^{\circ}(\mathrm{p}=0.39)$. The test in flexion to the average angle showed the following error indices: the right elbow $-6.43 \pm 11.24^{\circ}$, the left elbow $-8.55 \pm 11.59^{\circ}(\mathrm{p}=0.45)$. Flexion to the large angle showed such deviation from the needed degrees: on the right elbow $-9.69 \pm 12.12^{\circ}$, on the left elbow $-10.85 \pm 12.03^{\circ}(\mathrm{p}=0.69)$.

Repeated tests in flexion of elbow joints were hold after physical therapy program. Flection of the right elbow to the acute angle were performed satisfactorily by 101 persons $(41 \%)$, to the right angle -150 persons $(61 \%)$, to the obtuse angle 81 persons (33\%). As for the left elbow, repeated testing was successful in $115(47 \%), 123(51 \%)$ and $108(44 \%)$ persons, respectively with the specified angles of flection.

A comparative analysis of the error indicators of the flexion amplitude made possible to state an improvement in the proprioceptive sensitivity of people with severe visual impairment and blindness. So, the amplitude error in the series of the right limb flexion to the small angle decreased by $8.3 \%$, of the left limb - increased by $19.5 \%$. In the series of flexion to the average angle, the amplitude error on the right limb increased by $17.7 \%$, on the left limb - by $6.7 \%$. When flexing the right limb to the large angle, the amplitude error decreased by $25.8 \%$, the left limb - by $21.4 \%$.

Conclusions. The systematic and targeted use of physical therapy allowed the formation of proprioreceptive sensitivity and the creation of a basis for improving the spatial orientation of people with special needs who had pathologies of vision. A sufficient level of spatial orientation will increase social and physical activity, expand people's capabilities and improve quality of life indicators.

Key words: proprioceptive sensitivity, spatial orientation, blindness, severe visual impairment, physical therapy.

Конфлікт інтересів: відсутній.

Conflicts of interest: authors have no conflicts of interest to declare.

\section{Відомості про авторів}

Копитіна Яна Миколаївна - кандидат наук з фізичного виховання і спорту, доцент; м. Суми, Україна. +380 (99) 014-96-62, yana@ kopytin.in.ua.

Арсшина Юлія Борисівна - кандидат наук з фізичного виховання і спорту; м. Суми, Україна. +380 (66) 163-75-53, julia.opheart@gmail.com.

Перепеченко Олеся Миколаївна - Київський міський Центр соціальної, професійної та трудової реабілітації інвалідів, м. Київ, Україна.

+380 (66) 443-43-36, panilesya@ukr.net.

Бугаєнко Тетяна Вікторівна -кандидат педагогічних наук; м. Суми, Україна. +380 (95) 540-57-76, bugaenkotv@ukr.net.

Беспалова Оксана Олександрівна - кандидат педагогічних наук; м. Суми, Україна. +380 (99) 363-2797, i-ozon777@ bigmir.net. 